Housing Finance in the UK 


\section{Housing Finance in the UK}

An Introduction

Second Edition

Kenneth Gibb

Moira Munro

Madhu Satsangi 


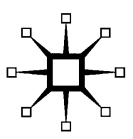

(c) Kenneth Gibb and Moira Munro 1991

(c) Kenneth Gibb, Moira Munro and Madhu Satsangi 1999

All rights reserved. No reproduction, copy or transmission of this publication may be made without written permission.

No paragraph of this publication may be reproduced, copied or transmitted save with written permission or in accordance with the provisions of the Copyright, Designs and Patents Act 1988, or under the terms of any licence permitting limited copying issued by the Copyright Licensing Agency, 90 Tottenham Court Road, London W1T 4LP.

Any person who does any unauthorised act in relation to this publication may be liable to criminal prosecution and civil claims for damages.

The authors have asserted their rights to be identified as the authors of this work in accordance with the Copyright, Designs and Patents Act 1988.

Published by

PALGRAVE MACMILLAN

Houndmills, Basingstoke, Hampshire RG21 6XS and

175 Fifth Avenue, New York, N. Y. 10010

Companies and representatives throughout the world

PALGRAVE MACMILLAN is the global academic imprint of the Palgrave Macmillan division of St. Martin's Press, LLC and of Palgrave Macmillan Ltd. Macmillan ${ }^{\circledR}$ is a registered trademark in the United States, United Kingdom and other countries. Palgrave is a registered trademark in the European Union and other countries.

ISBN 978-0-333-66436-0 ISBN 978-1-349-14117-3 (eBook)

DOI 10.1007/978-1-349-14117-3

This book is printed on paper suitable for recycling and made from fully managed and sustained forest sources.

A catalogue record for this book is available from the British Library.

Transferred to digital printing 2005 


\section{Contents}

List of Tables

viii

List of Figures ix

Preface to the Second Edition xi

1 Introducing Housing Finance 1

Introduction 1

Why does the UK housing finance system exist? 1

Why is housing finance important?

The management of the housing finance system $\quad 8$

How is the housing finance system analysed? 12

Housing needs in Britain $\quad 16$

Conclusions: housing finance and housing policy 19

Further reading $\quad 20$

Questions for discussion $\quad 20$

2 The Economics of Housing Markets 21

Introduction $\quad 21$

The market for owner-occupation $\quad 25$

Determinants of demand 28

Supply determinants $\quad 30$

The operation of the housing market 33

Conclusions $\quad 35$

Further reading 35

Questions for discussion $\quad 36$

3 Public Expenditure 37

Introduction $\quad 37$

Public expenditure: definitions, trends and patterns $\quad 40$

The development of public expenditure planning and control systems 46

Evaluation of the PES system $\quad 51$

Sub-national allocations of housing expenditure $\quad 56$

Local government finance $\quad 58$

Further reading $\quad 63$

Questions for discussion $\quad 64$ 
4 Financing Local Authority Housing 65

Introduction $\quad 65$

Historical background 65

The current system of funding local authorities $\quad 67$

$\begin{array}{ll}\text { Capital expenditure in England and Wales } & 70\end{array}$

Current expenditure in England and Wales $\quad 80$

Local authority finance: in retrospect and prospect $\quad 92$

Local authority finance in Scotland 94

$\begin{array}{ll}\text { Conclusions } & 98\end{array}$

Further reading $\quad 98$

Questions for discussion $\quad 99$

5 Financing Housing Associations $\quad 100$

Introduction 100

Housing associations: the context 102

Capital funding 107

Revenue funding $\quad 113$

Rent setting 116

Housing association accounts $\quad 119$

Conclusions 119

Further reading 120

$\begin{array}{ll}\text { Questions for discussion } & 121\end{array}$

6 Mortgage Finance, Housing and the Economy 122

$\begin{array}{ll}\text { Introduction } & 122\end{array}$

The UK housing market and mortgage finance 122

Mortgage products and house purchase 133

Deregulation and change in building societies 138

Taxation and home ownership 142

Capital grants to owner-occupiers 145

Housing and the economy 149

Conclusions: the cost of home ownership 154

Further reading 155

Questions for discussion 156

7 Private Rented Housing 157

$\begin{array}{ll}\text { Introduction } & 157\end{array}$

Rent controls and the private rented sector $\quad 160$

The private rented sector today 164

Recent reforms to the private rented sector $\quad 170$ 
Alternative reform for furnished private renting $\quad 174$ $\begin{array}{ll}\text { Conclusions } & 178\end{array}$

$\begin{array}{ll}\text { Further reading } & 179\end{array}$

Questions for discussion $\quad 179$

8 Help with Housing Costs 180

Introduction 180

Housing benefit in practice 181

Problems with the housing benefit system $\quad 190$

Reform to the existing system 196

Conclusions 200

Further reading 200

Questions for discussion 201

9 Key Issues in British Housing Finance 202

Introduction 202

From LSVTs to local housing companies and the PFI 202

Rent structures 209

Housing and urban regeneration 215

Paying for community care 221

Care in the community: Conclusions 231

Further reading 232

Questions for discussion 233

10 The Future of Housing Finance 234

Introduction 234

Recent trends and current context 234

Tenure-neutral reform? 237

Challenges for twenty-first century housing finance 239

Further reading $\quad 245$

Questions for discussion $\quad 245$

Bibliography 246

Index 253 


\section{List of Tables}

1.1 Tenure structure within the UK, 1996

1.2 Changing tenure structure in Great Britain, 1981 to 1995-6

3.1 General Government Expenditure by function, 1996-7

4.1 Total HRA in England, 1997-8

4.2 Trends in the English HRA, 1980-1, 1989-90 and 1997-8

4.3 The Scottish HRA, 1996-7

5.1 Average HAG and social housing grant rates, England and Scotland, 1990-1 to 1997-8

6.1 House price levels across the UK, 1980 to $1996 \quad 128$

6.2 Building societies, 1910 to 1995

7.1 Private renting across the UK, $1996 \quad 165$

7.2 Average cost of comprehensive repairs, private renting and all housing, England and Scotland, $1996 \quad 166$

7.3 Distribution of landlords by type, 1978 to 1993-4 168

8.1 Benefit levels: applicable amounts, 1998-9 183

8.2 Housing benefit means-tested income tapers, 1983 to 1995 


\section{List of Figures}

1.1 Households accepted as homeless in Great Britain, 1980 to 1996

2.1 Housing completions in the UK, 1980 to 1996

3.1 General Government Expenditure as a percentage of GDP, $1979-80$ to $2001-02$

3.2 Real and nominal changes in Total Managed Expenditure, 1990-1 to 2001-02

4.1 Houses sold under the right to buy, 1980 to 1995

4.2 Local authority housing capital investment in England, 1979-80 to 1995-6

4.3 Local authority rents in England, 1980 to $1996 \quad 88$

4.4 Local authority rents in Scotland, $1987-8$ to 1995-6 96

5.1 Capital expenditure on housing, and housing associations' share: (a) England and Wales, 1986-7 to 1995-6, and (b) Scotland, 1986-7 to 1996-7

5.2 The approved development programmes for England and Scotland, 1997-8

5.3 Housing association rents in Scotland and England, 1981 to 1996

6.1 House price and general inflation, 1974 to 1996

6.2 House price, earnings and retail price indices $(1993=100), 1986$ to $1997(Q 1)$

6.3 Property transactions, England and Wales, and mortgage advances, UK, 1980 to 1996

6.4 Mortgage arrears and repossessions, UK, 1981 to 1996

6.5 Advance-to-price ratios, 1981 to 1996

6.6 Distribution of mortgage loans by lender type, 1991 to 1996

6.7 MIRAS and Income Support payment of mortgage interest benefit for borrowers, $1979-80$ to $1997-98$

7.1 Private renting's share of tenure, 1981 to 1996

8.1 Housing benefit and Income Support for mortgage expenditure, Great Britain, 1980-81 to 1997-98 


\section{Preface to the Second Edition}

Since the first edition of Housing Finance in the $U K$ appeared in 1991, much has changed in the UK housing system, and there has been much improvement in our understanding of how it operates. The evidence of the house condition surveys of 1991 and 1996 attests to gradual improvements in housing and living standards for the majority of the population. And people's housing aspirations, if one accepts the results of countless satisfaction surveys as testimony, are more likely to be met in Britain now than in any other era. Yet even the most cursory research reveals that housing problems in this corner of the advanced industrial world have not been solved. Homelessness, rooflessness and squalor are not that far away, even from the leafier suburbs of our biggest cities. And access to the good things that an advancing society can bring material goods or cultural participation - is still fundamentally conditioned by where one lives. So, housing policy still matters. And understanding housing policy relies upon understanding the financial means by which policy is implemented, and the economic arguments why some policies might work, and some are bound for failure.

This is part of the rationale for the second edition, but only part. In the first edition, we alluded to information gaps or instances of poor data. Thanks to the efforts of scholars, students, government, practitioners and ordinary citizens, many of these have been filled. With the burgeoning of the global telephone exchange that is the Internet, it is ever easier to access ever more facts and figures. But we need to make sense of these data, to be able to put them into an organised framework of understanding housing finance and policy. We hope that the revised work makes a modest contribution to meeting that aim. Our work is as up to date as it is possible to be. But, inevitably, policy change and the passage of time bring new figures to supplement or supplant our data. Our aim is to provide keys to understanding that can withstand likely change. 
This work has been made easier by the efforts of many people. In particular, we acknowledge Steve Wilcox for his continuing data collation and analysis. Our colleagues Peter Kemp, Duncan Maclennan, Mark Stephens, Glen Bramley and Hal Pawson gave advice and encouragement and Jeane Jenkins, Heather Cruickshank and Jenny Ferguson made sense and order of our type and handwritten script. Errors of interpretation remain our responsibility.

KenNeth GibB

MoIra Munro

MADHu SATSANGi 